\title{
A família Orchidaceae na Reserva Biológica da Represa do Grama - Descoberto, Minas Gerais, Brasil
}

\author{
Luiz Menini Neto ${ }^{1}$ \\ Valquiria Rezende Almeida ${ }^{2}$ \\ Rafaela Campostrini Forzza ${ }^{3}$
}

\begin{abstract}
RESUMO
O estudo apresentado trata do levantamento das espécies de Orchidaceae ocorrentes na Reserva Biológica da Represa do Grama, localizada na Zona da Mata de Minas Gerais, no município de Descoberto. A Reserva abrange uma área de 263,8 hectares de floresta estacional semidecidual. A família Orchidaceae está representada na área por 23 gêneros e 28 espécies. Neste trabalho são fornecidas chave de identificação, descrições, ilustrações, distribuição geográfica e comentários para as espécies.
\end{abstract}

Palavras chave: Orchidaceae, Minas Gerais, Zona da Mata, taxonomia

\section{ABSTRACT}

A survey consist the taxonomic study of the Orchidaceae family in the Reserva Biológica da Represa do Grama, located at Zona da Mata of Minas Gerais, in the Descoberto's town. The area covers 263,8 hectares of stationary semidecidual forest. There were finded for the family 23 genera and 28 species. There are gived key to identification, descriptions, ilustrations, geographical distribution and comments for each species.

Key words: Orchidaceae, Minas Gerais, Zona da Mata, taxonomy

\section{INTRODUÇÃO}

Orchidaceae é uma das maiores famílias dentre as Fanerógamas, possuindo cerca de 19500 espécies e 775 gêneros (Judd et al. 1999). A família constitui aproximadamente $40 \%$ das Monocotiledôneas e ocorre por quase todas as regiões do planeta (Dahlgren et al., 1985). Pabst \& Dungs (1975, 1977), na última grande revisão das espécies brasileiras, apontaram cerca de 2350 espécies e 191 gêneros para o Brasil. Atualmente, acreditase que este número aproxima-se de 2400 espécies (Barros 1996).

Os membros da família Orchidaceae são ervas perenes com morfologia muito diversa. Epífitas, terrestres, rupícolas, hemiepífitas ou saprófitas; raízes com micorrizas, tuberosas ou não, em geral com velame. Caule simpodial ou monopodial, muitas vezes rizomatoso, mais raramente cormos, internós freqüentemente formando pseudobulbos. Folhas alternas, raramente opostas, dísticas ou espiraladas, simples, inteiras, com nervação usualmente paralelinérvia. Inflorescências racemosas ou paniculadas, algumas vezes reduzidas a uma única flor, terminais ou laterais. Flores usualmente monoclinas, zigomorfas, ressupinadas ou não, perianto tepalóide, em geral vistoso; sépalas 3, livres ou conatas; pétalas 3 , livres, a mediana diferenciada em labelo, as laterais semelhantes às sépalas; estames 1 ou 2 (raramente 3 ), adnatos ao estilete e ao estigma formando a coluna; pólen em geral agrupado em polínias; gineceu sincárpico, tricarpelar; estigma com um dos lobos não receptivo na face dorsal formando o rostelo, este podendo ou não formar estipe e/ou viscídio; ovário ínfero, unilocular com placentação parietal, ocasionalmente trilocular com placentação

${ }^{1}$ Acadêmico do Curso Ciências Biológicas da Universidade Federal de Juiz de Fora/ Bolsista de Conclusão de Curso UFJF. menini_neto@hotmail.com

${ }^{2}$ Acadêmico do Curso Ciências Biológicas da Universidade Federal de Juiz de Fora/Bolsista PIBIC/CNPq.

${ }_{3}^{3}$ Jardim Botânico do Rio de Janeiro, Rua Pacheco Leão 915, 22460-030, Rio de Janeiro, Brasil. rafaela@ jbrj.gov.br 
lateral; óvulos numerosos. Néctar em geral ausente, quando presente produzido em cálcar ou em nectários septais. Fruto cápsula, abrindo por (1-) 3 ou 6 fendas longitudinais; sementes minúsculas, com tegumento membranáceo, embrião muito reduzido; endosperma ausente (Dahlgren et al., 1985; Dressler, 1993).

A Reserva Biológica da Represa do Grama está localizada na Zona da Mata de Minas Gerais, no Município de Descoberto $\left(21^{\circ} 25^{\prime} \mathrm{S}\right.$ $42^{\circ} 56^{\prime} \mathrm{W}$ ), cerca de $100 \mathrm{~km}$ ao nordeste de Juiz de Fora, tendo sido a primeira Reserva Biológica criada no estado. A Reserva abrange uma área de 263,8 hectares de floresta estacional semidecidual montana e abriga dois córregos dos quais ocorre captação de água para abastecimento parcial dos municípios de Descoberto e de São João Nepomuceno.

A região da Zona da Mata de Minas Gerais é constituída por florestas estacionais semideciduais montana e submontana que se encontram extremamente fragmentadas (Meira Neto et al. 1997; Silva 2000), devido a diversos tipos de perturbações como o fogo, a agricultura, a pecuária, a retirada seletiva de madeira e o crescente desenvolvimento das áreas urbanas (Oliveira-Filho et al. 1994). Paradoxalmente, poucos estudos florísticos têm sido desenvolvidos nessa região. Esse fato está refletido nas coleções depositadas em nossos herbários, que representam muito pouco da diversidade das matas mineiras, e na escassa literatura sobre a flora da região.

Dentro desse contexto, o presente estudo objetivou apresentar o levantamento das espécies de Orchidaceae ocorrentes na Reserva Biológica da Represa do Grama com a finalidade de ampliar o conhecimento sobre a vegetação da Zona da Mata de Minas Gerais, incrementar o número de coleções depositadas em herbários e ampliar o conhecimento sobre a taxonomia e distribuição geográfica das espécies de Orchidaceae.

\section{MATERIAL E MÉTODOS}

Para o desenvolvimento deste trabalho foram realizadas coletas mensais à Reserva, no período de agosto de 1999 a agosto de 2002. As amostras de materiais férteis foram coletadas e incorporadas à coleção do Herbário CESJ. As duplicatas foram enviadas para diversos herbários nacionais, como indicado no material examinado de cada espécie. O material examinado representa os espécimes coletados na Reserva e encontrase citado em ordem cronológica de coleta. $\mathrm{O}$ material adicional representa exemplares de outras localidades.

As descrições das espécies foram elaboradas a partir dos materiais coletados na Reserva. Seis espécies não foram descritas por não apresentarem material fértil e encontramse citadas na tabela 1. As ilustrações foram elaboradas a mão livre utilizando estereomicroscópio. A terminologia morfológica adotada foi retirada das definições contidas em Radford et al. (1974) e Dressler (1981).

São apresentadas descrições, ilustrações, comentários sobre aspectos taxonômicos, informações sobre a distribuição geográfica de cada espécie e chave para identificação dos táxons ocorrentes na Reserva. Os dados de distribuição geográfica para cada espécie foram obtidos através da literatura e da análise do material adicional examinado.

Tabela 1 - Espécies que não floresceram durante o desenvolvimento do trabalho.

\begin{tabular}{ll}
\hline Espécie & Formade vida \\
\hline Campylocentrum cf. linearifolium Schltr. ex Mansf. & epífita \\
Catasetum sp. & epífita \\
Cyclopogon sp & terrestre \\
Gomesa cf. glaziovii Cogn. & epífita \\
Pleurothallis sp. & epífita \\
Zygopetalum sp. & terrestre \\
\hline
\end{tabular}




\section{CHAVE PARA IDENTIFICAÇÃO DAS ESPÉCIES DE ORCHIDACEAE OCORRENTES NA RESERVA BIOLÓGICA DA REPRESA DO GRAMA}

1. Ervas terrestres.

2. Caules intumescidos em pseudobulbos.

3. Folhas variegadas, planas ou conduplicadas, únicas por pseudobulbo .. 12.Oeceoclades maculata

3'. Folhas não variegadas, plicadas, mais de uma por pseudobulbo.

4. Planta com até $15 \mathrm{~cm}$ de altura

11. Liparis nervosa

4'. Plantas maiores que $50 \mathrm{~cm}$ de altura

20. Warrea warreana

2'. Caules não intumescidos em pseudobulbos.

5'. Plantas áfilas

21. Wullschlaegelia aphylla

5. Plantas com folhas.

6. Plantas caulescentes com folhas dísticas

17. Psilochilus modestus

6'. Plantas acaules com folhas rosuladas.

7. Flores pediceladas

18. Sauroglossum nitidum

7'. Flores sésseis.

8. Flores calcaradas

4. Eltroplectris janeirensis

8'. Flores sem cálcar

16. Prescottia stachyodes

1'. Ervas epífitas, rupícolas ou lianescentes.

9. Caules não intumescidos em pseudobulbos.

10. Plantas lianescentes

19. Vanilla cf. gardneri

10'. Plantas epífitas ou rupícolas.

11. Plantas com ramicaule, uma folha por ramicaule

13. Pleurothallis hypnicola

11'. Plantas sem ramicaule, multifoliadas.

12. Planta menor que $5 \mathrm{~cm}$ alt., margem foliar ciliada ...... 8. Eurystyles actinosophila

12'. Planta maior que $40 \mathrm{~cm}$ de alt., margem foliar glabra.

13. Folhas dísticas, flabeladas, inflorescência uniflora

10. Huntleya meleagris

13'. Folhas dísticas, não flabeladas inflorescência multiflora.

14. Inflorescência em panícula, flores castanho-amareladas

6. Epidendrum densiflorum

14'. Inflorescência em corimbo, flores róseas ..... 7. Epidendrum secundum

9'. Caules intumescidos em pseudobulbos.

15. Pseudobulbos 1-foliados

2. Comparettia coccinea

15'. Pseudobulbos 2- a multifoliados.

16. Duas folhas apicais por pseudobulbo.

17. Folhas pecioladas com nervuras salientes

22. Xylobium variegatum

17'. Folhas sésseis com nervuras não salientes.

18. Pseudobulbo piriforme, inflorescência no ápice do pseudobulbo ......

5. Encyclia patens

18'. Pseudobulbo levemente achatado, inflorescência na base do pseudobulbo

9. Gomesa recurva

16'. Mais de duas folhas por pseudobulbo.

19. Pseudobulbos piriformes

5. Encyclia patens

19'. Pseudobulbos ovais ou fusiformes.

20. Pseudobulbos fusiformes, com $12 \mathrm{~cm}$ ou mais de compr.

21. Inflorescência em racemo, flores diclinas

1. Catasetum cernuum

21'. Inflorescência em panícula, flores monoclinas ... 3. Cyrtopodium cardiochilum 
20'. Pseudobulbos ovais a fusiformes, menores que $3 \mathrm{~cm}$ compr.

22. Planta até $7 \mathrm{~cm}$ alt., inflorescência em racemo 14. Polystachya micrantha

22 '. Planta maior que $7 \mathrm{~cm}$ alt., inflorescência em panícula 13. Polystachya concreta

\section{RESULTADOS E DISCUSSÃO}

$\mathrm{Na}$ Reserva Biológica da Represa do Grama a família Orchidaceae está representada por 28 espécies distribuídas em 23 gêneros. Quanto à forma de vida foram registradas 14 espécies epífitas, nove terrestres, três rupícolas, uma hemiepífita lianescente e uma saprófita.

1. Catasetum cernuum (Lindl.) Rchb. f., Ann. Bot. Syst. 6: 570. 1863.

Figura $1 \mathrm{a}$

Erva epífita, ca. $40 \mathrm{~cm}$ alt. Pseudobulbos verdes, $12-20 \mathrm{~cm}$ compr., fusiformes, ca. 10foliados, os mais velhos sulcados. Folhas dísticas, dispostas ao longo do pseudobulbo; bainha foliar ca. 6 × $3 \mathrm{~cm}$, alva; lâmina verde, levemente discolor, 15-30 x 7-9,3 cm, oblanceolada, nervuras longitudinais salientes, sésseis, ápice cuspidado. Inflorescência masculina ca. $65 \mathrm{~cm}$ compr., em racemo, multiflora, laxa, ápice pendente, lateral. Pedúnculo verde-claro, ca. $45 \mathrm{~cm}$ compr., ereto. Brácteas do pedúnculo verdes a cremeesverdeadas, 1,5-2 cm compr., lanceoladas a obovadas, amplectivas sobre o pedúnculo, ápice agudo. Brácteas florais verdes, 1-1,8 x 0,3-0,7 cm, lanceoladas, ápice agudo. Flores masculinas pediceladas; pedicelo creme a verde, ca. 1,6 cm compr.; sépala dorsal vinácea, ca. 3,6 x 1,1 cm, elíptica, côncava, recobrindo parte das pétalas, ápice agudo; sépalas laterais vináceas, ca. 3,6 x 1,3 cm, elípticas, côncavas, patentes, ápice agudo; pétalas verdes com máculas vináceas, ca. 3,4 x $1 \mathrm{~cm}$, elípticas, convexas, ápice agudo; labelo vináceo, trilobado, ca. $1,8 \times 2,1 \mathrm{~cm}$, plano, patente, dois lobos laterais com ápice acuminado, lobo central triangular e carnoso; coluna verde com máculas vináceas, ca. 1,8 cm compr., ereta, rostrada; rostro ca. $3 \mathrm{~mm}$ compr.; duas antenas retrorsas se projetando em direção ao disco do labelo, ca. $1,5 \mathrm{~cm}$ compr., paralelo-divaricadas; polínias 2, ca. 4 mm compr., amarelas, estipe ca. $4 \mathrm{~mm}$ compr., oblongo, castanho, viscídio ca. $2 \mathrm{~mm}$ diâm, orbicular, castanho. Inflorescência feminina ca. $22 \mathrm{~cm}$ compr., em racemo, pauciflora, laxa, ereta, lateral. Pedúnculo verde-claro, ca. 17 $\mathrm{cm}$ compr., ereto. Brácteas do pedúnculo verdes, 1,8-2 cm compr., obovadas a lanceoladas, amplectivas sobre o pedúnculo, ápice agudo. Brácteas florais verdes ca. 2 x $0,7 \mathrm{~cm}$, lanceoladas, ápice agudo. Flores femininas carnosas, pediceladas; pedicelo ca. $1,8 \mathrm{~cm}$ compr.; pétalas e sépalas verdes com máculas castanhas; labelo verde, cuculado; ovário ca. 1,5 cm compr. Fruto não visto.

Material examinado: BRASIL. MINAS GERAIS. Descoberto. Reserva Biológica da Represa do Grama: 11.XI.2001, V. R. Almeida et al. 23, fl. (CESJ); 26.I.2002, R. C. Forzza \& B. K. S. Franco 2053, fl. (CESJ).

O gênero Catasetum inclui mais de 100 espécies exclusivamente neotropicais, com a grande maioria concentrada na região amazônica, principalmente nos estados do Amazonas e Pará (Silva \& Oliveira, 1998). C. cernuum apresenta flores muito vistosas, em geral diclinas. Na Reserva ocorrem tanto plantas com inflorescências masculinas e femininas, quanto plantas com inflorescências com flores hermafroditas. Na Reserva $C$. cernuum se desenvolve sempre entre as bainhas foliares de Attalea oleifera Barb. Rodr. Apresenta ocorrência registrada para os estados das Regiões Sudeste e Sul do Brasil, exceto o Paraná (Pabst \& Dungs, 1975).

2. Comparettia coccinea Lindl., Sketch Veg. Swan R. 14: t. 68. 1838.

Figura $1 \mathrm{~b}$

Erva epífita, ca. $43 \mathrm{~cm}$ alt. Pseudobulbo verde-claros, ca. $2 \mathrm{~cm}$ compr., fusiforme, 1 folhados. Folha séssil; lâmina 4,9-16 x 0,9-1,5 

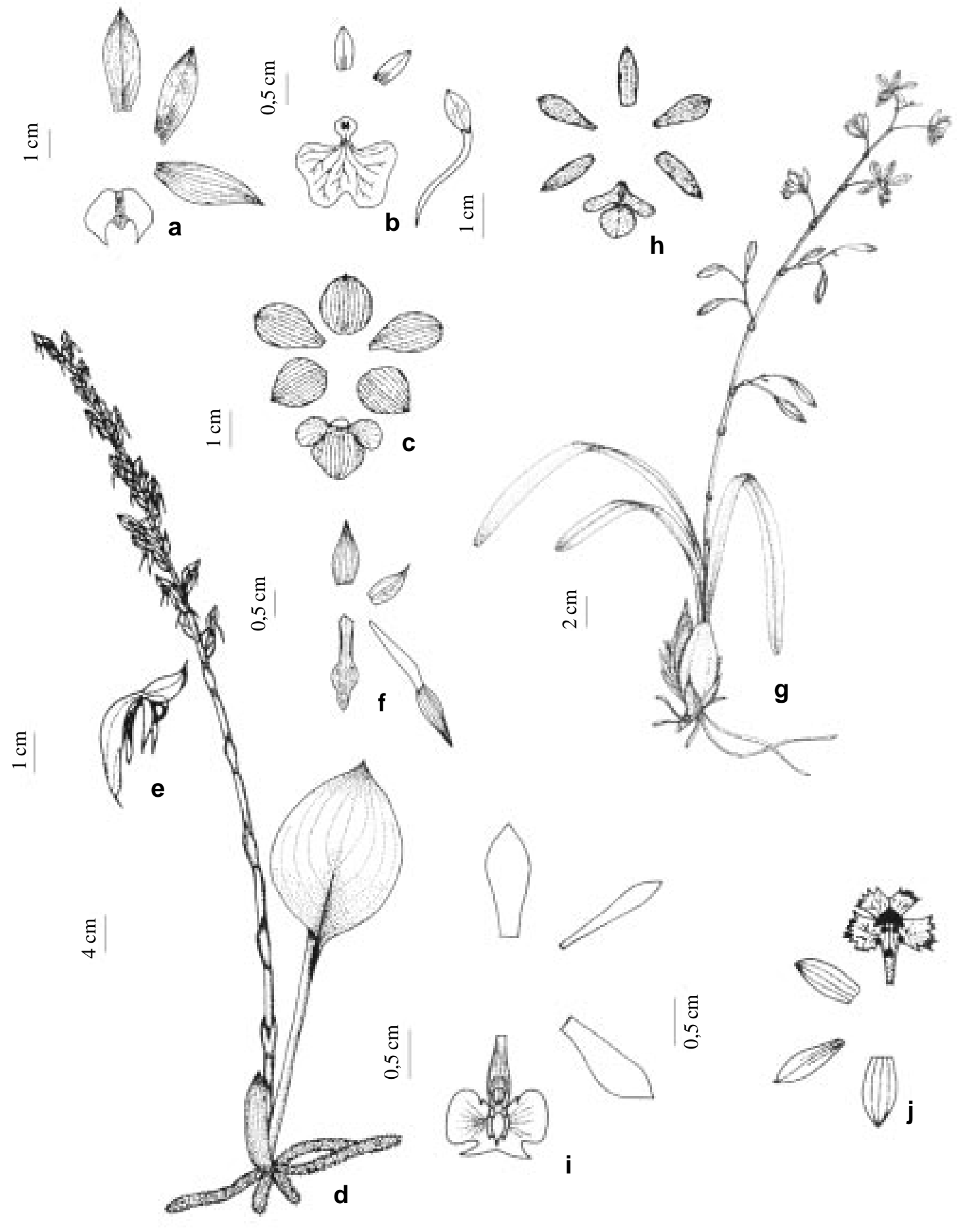

Figura 1. a. Catasetum cernuum; b. Comparettia coccinea; c. Cyrtopodium cardiochilum; d-f Eltroplectris janeirensis; gh. Encyclia patens; i. Epidendrum densiflorum; j. E. secundum. 
$\mathrm{cm}$, oblanceolada, levemente sulcada na nervura central, ápice arredondado, algumas vezes acuminado. Inflorescência ca. $43 \mathrm{~cm}$ compr., em racemo, pauciflora, laxa, pendente, lateral. Pedúnculo verde-claro, ca. $35 \mathrm{~cm}$ compr., ereto. Brácteas do pedúnculo estramíneas, ca. $5 \times 3 \mathrm{~mm}$, lanceoladas, ápice agudo. Brácteas florais 2-4 x $2 \mathrm{~mm}$, lanceoladas, ápice agudo. Flores pediceladas, laranja-avermelhadas, calcaradas; pedicelo ca. $1,5 \mathrm{~cm}$ compr.; sépala dorsal ca. 7 × $3 \mathrm{~mm}$, elíptica, côncava, livre, ápice agudo; sépalas laterais ca. 6 × $2 \mathrm{~mm}$, conatas, base do sinsépalo estendido em cálcar; cálcar ca. 1,9 cm compr.; pétalas ca. 8 x $3 \mathrm{~mm}$, lanceoladas, ápice agudo, côncavas; labelo ca. 1,5 x 1,5 cm, trilobado, com dois calos entre os lobos laterais; lobos laterais muito reduzidos, ca. $1 \mathrm{~mm}$ larg., semicirculares; lobo central evidente, ca. $1 \mathrm{x}$ $1,5 \mathrm{~cm}$, bilobado, ápice retuso; coluna ca. 4 mm compr., ca. $3 \mathrm{~mm}$ diâm.; polínias não vistas; ovário ca. $1 \mathrm{~cm}$ compr. Fruto não visto.

Material examinado: BRASIL. MINAS GERAIS. Descoberto. Reserva Biológica da Represa do Grama: 01.IV.2000, P. C. L. Faria et al. s.n., fl. (CESJ 31100); 10.III.2002, L. S. Fernandes s.n., fl. (CESJ 36624, MBM).

O gênero Comparettia possui 10 espécies (Dressler, 1993), das quais duas são registradas para o Brasil, $C$. coccinea e $C$. paulensis Cogn. (Pabst \& Dungs, 1977). C. coccinea apresenta flores vistosas, de intensa coloração laranja-avermelhada. Esta espécies é uma das mais raras na Reserva tendo sido observada apenas uma pequena população. Distribui-se pelos estados da Região Sudeste, Paraná e Distrito Federal (Pabst \& Dungs, 1977).

3. Cyrtopodium cardiochilum Lindl., J. Hort. Soc. London 4: 266. 1849.

Figura $1 \mathrm{c}$

Erva rupícola. Pseudobulbos amarelos, fusiformes, multifoliados, com bainhas persistentes, amplectivas sobre o pseudobulbo. Folhas dísticas, dispostas ao longo do pseudobulbo; bainha foliar 6,5-8,5 x 1,5-4,5 cm; lâmina 19-60 x 2-7,5 cm, lanceolada, nervuras longitudinais salientes, sésseis sobre a bainha, ápice longo-acuminado. Inflorescência ca. 1,5 m compr., em panícula, multiflora, laxa, ereta, lateral. Pedúnculo ca. $1 \mathrm{~m}$ compr., ereto. Brácteas florais amarelas, 1-2 x 0,5-1 cm, elípticas, ápice agudo a apiculado. Flores pediceladas, amarelas; pedicelo ca. $2 \mathrm{~cm}$ compr.; sépalas ca. 1,6 x 1,3 cm, orbiculares, ápice arredondado; pétalas ca. 2 x 1,3 cm, obovais, ápice arredondado; labelo amarelo, ca. $1,7 \times 2,1 \mathrm{~cm}$, trilobado, lobos laterais levemente reniformes, ca. 7 × $9 \mathrm{~mm}$, com máculas vináceas, lobo central suborbicular, ca. 1,2 x 1,3 cm, ápice arredondado; coluna ca. $8 \mathrm{~mm}$ compr., pé da coluna ca. $3 \mathrm{~mm}$ compr.; polínias 2, amarelas, ovais, ca. $1 \mathrm{~mm}$ compr., 1sulcadas, estipe ca. $1 \mathrm{~mm}$ compr., viscídio castanho, triangular, ca. $1 \mathrm{~mm}$ larg.; ovário ca. $8 \mathrm{~mm}$ compr. Fruto imaturo ca. $3,5 \mathrm{~cm}$ compr. Material examinado: BRASIL. MINAS GERAIS. Descoberto. Reserva Biológica da Represa do Grama: 21.X.2001, F. R. G. Salimena \& P. H. Nobre 933, fl. (BHCB, CESJ, CTES, MBM, SP, SPF, UB).

Cyrtopodium é um gênero amplamente distribuído nas Américas, ocorrendo desde a Flórida (EUA) até a Argentina, com centro de diversidade no Brasil (32 espécies), mais precisamente no Planalto Central Brasileiro (Menezes, 2000). C. cardiochilum é facilmente confundida com $C$. andersonii $\mathrm{R}$. Br. Segundo Menezes (2000) esta última possivelmente ocorre no território brasileiro apenas no estado do Amapá, sendo $C$. cardiochilum a espécie das regiões serranas de Minas Gerais e Rio de Janeiro. Pode ser facilmente diferenciada das demais espécies encontradas na Reserva pelos pseudobulbos longos e amarelos, pela ampla inflorescência e pelas flores amarelas.

4. Eltroplectris janeirensis (Porto \& Brade) Pabst, Bradea 1 (47): 469. 1974.

Figura $1 \mathrm{~d}-\mathrm{f}$

Erva terrestre, ca. $40 \mathrm{~cm}$ alt. Caule não intumescido em pseudobulbo. Folhas 
pecioladas; pecíolo róseo, 20-24 cm compr.; lâmina verde, discolor, variegada, 16-19,5 x 9,5 $\mathrm{cm}$, oval, base atenuada ápice acuminado. Inflorescência ca. $15 \mathrm{~cm}$ compr., em espiga, multiflora, laxa, ereta. Pedúnculo róseo, ca. 55$68 \mathrm{~cm}$ compr., terminal, ereto. Brácteas do pedúnculo castanhas, 1,6-2,7 x $1 \mathrm{~cm}$, lanceoladas, ápice acuminado a longoacuminado, amplectivas sobre o pedúnculo. Brácteas florais róseas, 1-1,8 x 0,2-0,4 cm, lanceoladas, ápice agudo a longo-acuminado. Flores sésseis, verdes, calcaradas; sépala dorsal 9 x 4 mm, lanceolada, côncava, ápice agudo; sépalas laterais ca. 7 × $3 \mathrm{~mm}$, lanceoladas, ápice agudo; cálcar $1,2 \mathrm{~cm}$ compr., formado pelo prolongamento das sépalas laterais mais o pé da coluna, fundido apenas na base; pétalas ca. 8 × $4 \mathrm{~mm}$, lanceoladas, levemente assimétricas, ápice agudo; labelo ca. $1,7 \times 0,5 \mathrm{~cm}$, com a base estreitada, oblonga, inserida dentro do cálcar, expandindo aproximadamente a partir do meio em uma lâmina trilobada, ca. $8 \mathrm{~mm}$ compr., lobo central triangular, ca. $4 \times 2 \mathrm{~mm}$, ápice agudo, lobos laterais semicirculares, ca. 4 x 1 $\mathrm{mm}$; coluna ca. $4 \mathrm{~mm}$ compr., rostrada; rostro ca. $1 \mathrm{~mm}$ compr., filiforme; polínias não vistas; ovário ca. 2,3 cm compr., fusiforme. Fruto não visto.

Material examinado: BRASIL. MINAS GERAIS. Descoberto. Reserva Biológica da Represa do Grama: 29.IV.2000, P. C. L. Faria et al. s.n., fl. (CESJ 31136); 20.IV.2002, R. C. Forzza et al. 2171, fl. (CESJ, MBM).

O gênero Eltroplectris possui 13 espécies (Dressler, 1993) nativas dos trópicos e subtrópicos do continente americano (Garay, 1980). Para o Brasil são registradas dez espécies (Pabst \& Dungs, 1975; Campacci \& Kautsky, 1999). E. janeirensis apresenta distribuição restrita aos estados de Minas Gerais e Rio de Janeiro (Pabst \& Dungs, 1975). Na Reserva foram observados poucos indivíduos, sempre em locais úmidos e sombreados. Dentre as espécies terrestres encontradas na Reserva, é a única que possui calcar evidente.
5. Encyclia patens Hook., Bot. Mag. 57: t. 3013. 1830.

Figura $1 \mathrm{~g}$-h

Erva epífita, ca. $38 \mathrm{~cm}$ alt. Pseudobulbos verde-claros, ca. 5,5 cm compr., piriformes, 2-3folhados. Folhas sésseis, apicais; lâmina 19-30 x 1,2-1,7 cm, loriformes, ápice retuso. Inflorescência 20-34 cm compr., em panícula, pauciflora a multiflora, laxa, ereta, terminal. Pedúnculo 10-14 cm compr. Brácteas do pedúnculo estramíneas, 0,5-1 cm compr., obovais, amplectivas sobre o pedúnculo, ápice agudo. Flores pediceladas, creme com máculas vináceas; pedicelo ca. $5 \mathrm{~mm}$ compr; sépala dorsal ca. 1,4 x 0,4 cm, oblanceolada, ápice agudo; sépalas laterais ca. 1,3 x 0,4 cm, elípticas, ápice acuminado; pétalas ca. $1,4 \times 0,5 \mathrm{~cm}$, espatuladas, ápice agudo; labelo ca. 1,2 x 1,5 cm, trilobado, lobos laterais ca. $7 \times 2 \mathrm{~mm}$, oblongos, ápice arredondado, lobo central 6 x $6 \mathrm{~mm}$, orbicular, ápice arredondado a apiculado; coluna ca. $7 \mathrm{~mm}$ compr., com duas pequenas alas laterais próximas do ápice; polínias 4, amarelas; ovário ca. $1 \mathrm{~cm}$ compr. Fruto não visto.

Material examinado: BRASIL. MINAS GERAIS. Descoberto. Reserva Biológica da Represa do Grama: 24.VI.2000, F. R. G. Salimena et al. s.n., fl. (CESJ 31246); 27.V.2001, V. R. Almeida et al. 7, fl. (CESJ); VI.2001, R. M. Castro 538, fl. (CESJ, MBM). Material adicional examinado: BRASIL. RIO DE JANEIRO. Rio de Janeiro. Morro Queimado, 22.V.1972, D. Sucre et al. 9514, fl. (RB); Petrópolis. \pm 1100 m.s.m., Araras, 16.VI.1974, G. Martinelli 325, fl. (RB). PARANÁ. Baía de Guaratuba, 12.VII.1969, P. I. S. Braga et al. 1674, fl. (RB).

Encyclia patens possui flores e hábito semelhante à E. oncidioides Schltr., embora tenha tanto o porte quanto as flores menores do que esta (Castro Neto \& Campacci, 2000). Tem como um de seus sinônimos mais conhecidos a E. odoratissima (Lindl.) Schltr. Ocorre nos estados das Regiões Sul, Sudeste e Bahia (Pabst \& Dungs, 1977). Na Reserva foram observados poucos indivíduos, ocorrendo sempre na borda dos cursos d'água. 
6. Epidendrum densiflorum Hook., Bot. Mag. 67: t. 3791. 1840.

Figura $1 \mathrm{i}$

Erva rupícola ou epífita, ca. $1 \mathrm{~m}$ alt. Caule não intumescido em pseudobulbo. Folhas numerosas, dísticas; bainha foliar ca. $3 \mathrm{~cm}$ compr.; lâmina verde-escura, 11-18 x 3-5 cm, elíptica, margem inteira, séssil sobre a bainha, ápice agudo. Inflorescência ca. 23,5 cm compr., em panícula, multiflora, laxa, ereta, terminal. Pedúnculo verde, ca. $6,5 \mathrm{~cm}$ compr., ereto. Brácteas do pedúnculo 1-1,5 x 0,5 cm, lanceoladas, ápice acuminado. Brácteas florais 5 x $3 \mathrm{~mm}$, lanceoladas, ápice agudo a acuminado. Flores castanho-amareladas, pediceladas; pedicelo ca. 1,5 cm compr.; sépalas 1,2 × 0,4 cm, oblanceoladas, côncavas, ápice agudo; pétalas ca. 1,2 x 0,2 cm, oblanceoladas, ápice agudo; labelo tetralobado, ca. $0,8 \times 1 \mathrm{~cm}$; lobos laterais reniformes ca. 6 $\mathrm{x} 4 \mathrm{~mm}$, com uma pequena reentrância próximo à base; lobos centrais triangulares, 3 x $2 \mathrm{~mm}$, ápice agudo; disco com dois calos arredondados na base da lâmina, próximos à junção com a coluna, três calos transversais, alongados, na região do disco, sendo o central mais longo que os demais; coluna ca. $7 \mathrm{~mm}$ compr.; polínias 4, levemente assimétricas, duas maiores, ovais, duas menores, obovais; ovário ca. $1 \mathrm{~cm}$ compr. Frutos verdes, 2-3 cm compr., fusiformes.

Material examinado: BRASIL. MINAS GERAIS. Descoberto. Reserva Biológica da Represa do Grama: 07.V.2001, R. M. Castro et al. 314, fr. (CESJ, MBM), 21.IX.2002, L. Menini Neto et al. 2, fl. (CESJ).

Material adicional examinado: BRASIL. MINAS GERAIS. Carangola: 17.X.1989, L. S. Leoni s.n., fl. (CESJ 20943). Pirapitinga: IX.1989, S. M. S. Verardo \& M. Brügger s.n., fl. (CESJ 24189). Ituiutaba: Furna de São Vicente, 15.IX.1948, s.c., fr. (RB 66365). ESPÍRITO SANTO. Cultivada no Jardim Botânico do Rio de Janeiro, X.1939, s.c., fl. (RB 41471); ib. 21.X.1941, s.c., fl. (RB 46205). RIO DE JANEIRO. Rio de Janeiro. Baía de Sepetiba, Ilha Furtada, 5.XI.1967, D. Sucre
1883, fl. (RB). SÃO PAULO. Caçapava. cultivada no Jardim Botânico do Rio de Janeiro, 1935, P. Campos-Porto s.n., fl. (RB 37309). PARANÁ. Parque Nacional do Iguaçú, Matas do Palmital, 20.V.1949, A. P. Duarte 1898, fl. (RB). Sem procedência, s.d., W. Schwacke 11100, fl. (RB).

Epidendrum é um dos maiores gêneros dentro de Orchidaceae, possuindo cerca de 800 espécies distribuídas por todo continente americano (Dressler, 1993). Para o território brasileiro são referidas aproximadamente 100 espécies (Pabst \& Dungs, 1975). E. densiflorum apresenta ampla distribuição geográfica, ocorrendo por toda América Central e América do Sul (Pabst \& Dungs, 1975). Na Reserva essa espécie foi encontrada como epífita ou rupícola sempre próxima de cursos d'água.

7. Epidendrum secundum Jacq., Enum. Syst. Pl. 29. 1760.

Figura $1 \mathrm{j}$

Erva rupícola, 0,5-1 m alt. Caule não intumescido em pseudobulbo. Folhas numerosas, dísticas; bainha foliar amplexicaule; lâmina verde, 3-11 x 1,5-3 cm, oblongo-elíptica, séssil sobre a bainha, ápice obtuso. Inflorescência 4-22 cm compr., em corimbo, multiflora, laxa, ereta, terminal. Pedúnculo verde, ereto. Brácteas do pedúnculo $4-7 \mathrm{~cm}$ compr., estramíneas, amplectivas sobre o pedúnculo, ápice agudo. Brácteas florais 0,2-1,5 $\mathrm{x} 0,3 \mathrm{~cm}$, triangulares, ápice agudo a acuminado. Flores róseas, pediceladas; pedicelo verde, ca. $1,5 \mathrm{~cm}$ compr.; sépala dorsal ca. $8 \times 3 \mathrm{~mm}$, elíptica, ápice agudo; sépalas laterais ca. 8 x $4 \mathrm{~mm}$, oblongo-lanceoladas, ápice agudo; pétalas ca. 9 x 2 mm, espatuladas, ápice agudo; labelo róseo com disco alvo ou amarelo, ca. 9 x $4 \mathrm{~mm}$, trilobado, lobos laterais flabeliformes, fimbriados, lobo mediano levemente bilobado, flabeliforme, margem denteada, mais amplo que os laterais, disco com calos multilobados projetando-se em direção aos lobos laterais e central; coluna ca. 4 mm compr.; polínias 4 . Frutos verdes ca. $1,9 \mathrm{~cm}$ compr. 
Material examinado: BRASIL. MINAS GERAIS. Descoberto. Reserva Biológica da Represa do Grama: 10.VIII.2001, R. M. Castro et al. 583, fl./fr. (BHCB, CESJ, CTES, HUFU, MBM, RB, SP, SPF, UB); 26.I.2002, R. C. Forzza \& B. K. S. Franco 2059, fl. (BHCB, CESJ, MBM, UB).

Epidendrum secundum é uma espécie com circunscrição bastante complexa. Barros $(1996,2002)$ e Toscano-de-Brito (1995) tratamna como uma espécie única com grande variação morfológica. Esta posição foi corroborada por Pinheiro \& Barros (2002), após a realização de uma análise morfométrica com caracteres vegetativos e florais de indivíduos do "complexo Epidendrum secundum". E. secundum apresenta uma ampla distribuição geográfica, ocorrendo por todo território brasileiro, norte da América do Sul, América Central chegando até o México (Pabst \& Dungs, 1975). Na Reserva forma grandes populações, sempre como rupícola nos afloramentos do Ribeirão do Grama.

8. Eurystyles actinosophila (Barb. Rodr.) Schltr., Repert. Spec. Nov. Veg. Beih. 35: 39. 1925.

Figura $2 \mathrm{a}-\mathrm{b}$

Erva epífita, ca. $4 \mathrm{~cm}$ alt. Caule não intumescido em pseudobulbo. Folhas séssil, rosuladas; lâmina glauca, 1-2,6 x 0,5-1 cm, espatulada, margem ciliada, ápice acuminado. Inflorescência ca. $3 \mathrm{~cm}$ compr., capituliforme, multiflora, congesta, pendente, terminal. Pedúnculo ca. 2,5 cm compr., piloso. Brácteas do pedúnculo ca. 1 x $0,3 \mathrm{~cm}$, rômbicas, margem ciliada, ápice acuminado. Brácteas florais ca. 1,2 cm compr., rômbicas, margem ciliada, ápice acuminado. Flores pediceladas, alvas, com as peças eretas formando um tubo; sépalas ca. $4 \mathrm{x}$ $1 \mathrm{~mm}$, lanceoladas, ápice agudo; pétalas ca. $3 \mathrm{x}$ $0,5 \mathrm{~mm}$, oblongas, justapostas à sépala dorsal, ápice obtuso; labelo ca. 4 × $1 \mathrm{~mm}$, triangular, com duas projeções laterais na base, piloso próximo ao ápice, ápice agudo; polínias não vistas; ovário ca. $1 \mathrm{~mm}$ compr. Fruto não visto.

Material examinado: BRASIL. MINAS GERAIS. Descoberto. Reserva Biológica da
Represa do Grama: 21.II.2001, R. M. Castro et al. 125, fl. (BHCB, CESJ, SP, UB); R. M. Castro et al. 241, 01.IV.2001, fl. (CESJ); VI.2001, R. M. Castro 456, fl. (CESJ, MBM). Material adicional examinado: BRASIL. RIO DE JANEIRO. Paraty. Passando a $1^{\mathrm{a}}$ ponte, entrar à direita (sentido RJ/SP), $13 \mathrm{~km}$ do trevo de Paraty, subindo o Rio Corisco, 29.VI.1993, R. Marquete et al. 1064, fl. (RB); Resende. Itatiaia, III.1942, A. C. Brade 18014, fl. (RB).

O gênero Eurystyles possui 10 espécies (Dressler, 1993) distribuídas por toda região neotropical (Garay, 1980). Para o Brasil Pabst \& Dungs (1975) registraram quatro espécies. E. actinosophila apresenta distribuição geográfica restrita aos estados de Minas Gerais, Rio de Janeiro e São Paulo. Na Reserva são encontrados poucos indivíduos distribuídos, em geral, próximo de cursos d'água. E. actinosophila pode ser facilmente diferenciada das demais espécies da área por seu porte reduzido, suas folhas glaucas com margens ciliadas e por sua inflorescência congesta, capituliforme.

9. Gomesa recurva Lodd., Bot. Cab. t. 660. 1822 .

Figura 2 c-e

Erva epífita, ca. $45 \mathrm{~cm}$ alt. Pseudobulbos verdes, 5,5-7,7 cm compr., levemente achatados, 2-foliados, com 1-2 bainhas foliadas, basais. Folhas apicais; lâmina 18-36,5 x 1,5-3,5 cm, lanceoladas a oblanceoladas, ápice agudo a acuminado. Bainhas foliadas verdes, dobradas longitudinalmente $6,5-19 \times 1,5-1,5 \mathrm{~cm}$, lanceoladas, ápice agudo. Inflorescência 13,2$39,5 \mathrm{~cm}$ compr., em racemo, multiflora, laxa, recurvada, lateral. Pedúnculo verde, $6,6-17,5 \mathrm{~cm}$ compr., recurvado. Brácteas do pedúnculo verde-claras, 1,5-2,5 x 0,3-0,5 cm, lanceoladas, ápice agudo a acuminado. Brácteas florais verdeclaras, 2-12 x 1-2 mm, elípticas a lanceoladas, ápice agudo a acuminado. Flores pediceladas, amarelas a verde-amareladas; pedicelo ca. 0,8 cm compr.; sépala dorsal ca. 1 x 0,3 cm, oblanceolada, ápice agudo a arredondado; sépalas 

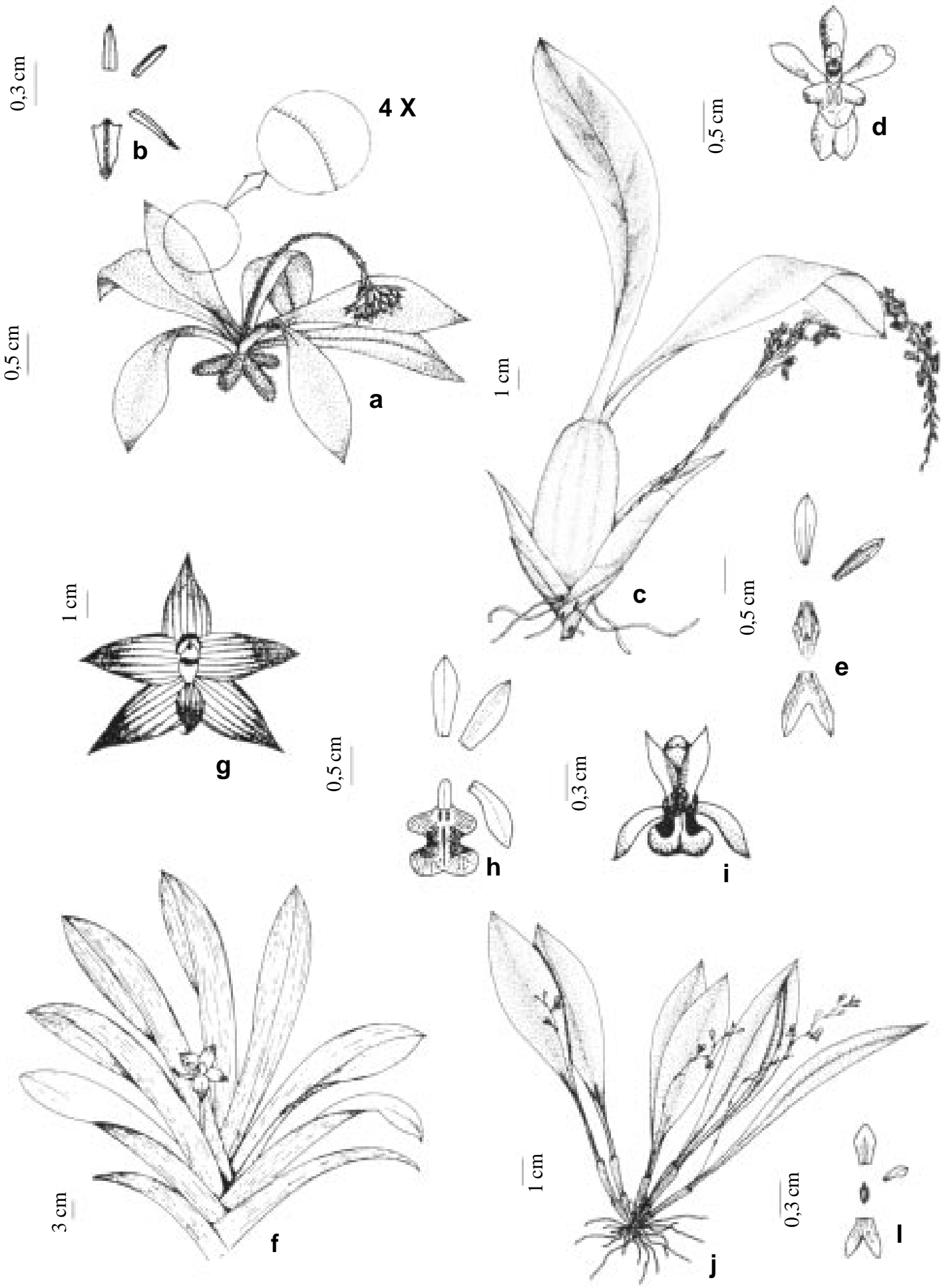

Figura 2. a-b. Eurystyles actinosophila; c-e. Gomesa recurva; f-g. Huntleya meleagris; h-i. Oeceoclades maculata; j-1. Pleurothallis hypnicola. 
laterais ca. 1 x 0,5 cm, lanceoladas, ápice agudo, conatas até a região mediana; pétalas ca. 9 × 3 mm, oblanceoladas, ápice agudo a arredondado; labelo genuflexo ca. 1 x 0,4 cm, elíptico, ápice agudo, com duas alas laterais e dois calos centrais claviformes; coluna ca. $6 \mathrm{~mm}$ compr.; polínias 2, obovais, ca. $1,5 \mathrm{~mm}$, amarelas, estipe ca. 1 mm compr., alvo, oblongo, viscídio ca. $1 \mathrm{~mm}$ compr., castanho, triangular; ovário ca. $4 \mathrm{~mm}$ compr. Fruto não visto.

Material examinado: BRASIL. MINAS GERAIS. Descoberto. Reserva Biológica da Represa do Grama: 25.V.2000, P. C. L. Faria et al. s.n., fl. (CESJ 31067); 10.I.2001, R. M. Castro et al. 92, fl. (BHCB, CESJ, UB); 21.IV.2001, R. M. Castro et al. 263, fl. (CESJ, MBM); 27.I.2002, R. C. Forzza \& B. K. S. Franco 2068, fl. (CESJ, SP); II.2002, P. C. L. Faria \& B. K. S. Franco s.n., (CESJ 39080, floresceu em cultivo em II.2002); III.2002, $R$. C. Forzza et al. s.n. (CESJ 39079, floresceu em cultivo em V.2002), fl. (CESJ); 21.IV.2002, R. M. Castro et al. 263, fl. (CESJ).

Material adicional examinado: BRASIL. PERNAMBUCO. Zona da Mata, 20.X.1968, A. B. G. Ferreira s.n., fl. (HB 42192). ESPÍRITO SANTO. Vargem Alta. 700 m.s.m., 24.V.1976, E. Lima s.n., fl. (HB 63524). MINAS GERAIS. São Mateus. Mata do Rio do Peixe, 15.VI.1968, V. Gomes 5, fl. (HB); Estação Experimental de Água Limpa, 18.II.1968, V. Gomes 03, fl. (HB); PARANÁ. Guaraqueçaba. Serrinha, 08.III.1968, G. Hatschbach 18686, fl. (HB). SANTA CATARINA. Palhoça. Morro Cambirela, 30.X.1956, J. A Rohr 2304, fl. (HB). RIO GRANDE DO SUL. Serra do Matador, 25.I.1959, R. Reitz \& R. Klein 8297, fl. (HB).

O gênero Gomesa possui 13 espécies exclusivamente brasileiras (Dressler, 1993). $G$. recurva é a espécie de Orchidaceae mais freqüente na Reserva, ocorrendo sempre à beira dos córregos, muitas vezes formando grandes populações que revestem os galhos das árvores. Apresenta distribuição nos estados das Regiões Sudeste e Sul do Brasil, exceto Rio Grande do Sul (Pabst \& Dungs, 1977).
10. Huntleya meleagris Lindl., Bot. Reg. 23: t. 1991.1837.

Figura $2 \mathrm{f}-\mathrm{g}$

Erva epífita, ca. $50 \mathrm{~cm}$ alt. Caule não intumescido em pseudobulbo. Folhas flabeladas, dísticas; bainha foliar 3-9,5 x 2,5 cm; lâmina levemente discolor, 25-37 x 1,5-4,2 cm, oblanceolada, com nervuras longitudinais salientes, séssil sobre a bainha, ápice agudo. Inflorescência uniflora. Pedúnculo 7,5-8 cm compr., ereto. Brácteas do pedúnculo ca. $1,5 \mathrm{~cm}$ compr., elípticas, amplectivas sobre o pedúnculo, ápice agudo. Brácteas florais ca. 1,3 x 0,2 cm, filiformes. Flores pediceladas, castanhoavermelhadas, com sépalas e pétalas de base alva a levemente amarelada; pedicelo 3-6,5 cm compr.; sépalas 3-3,5 x $1 \mathrm{~cm}$, lanceoladas, ápice atenuado; pétalas ca. $2,5 \times 1 \mathrm{~cm}$, lanceoladas, ápice atenuado; labelo alvo com ápice castanho, ca. 2 x 1,4 cm, obovado, ápice apiculado, calo com projeções fimbriadas; coluna alva, ca. 1,3 cm compr., com alas amarelo-esverdeadas; polínias 4, amarelo-claras, ca. $3 \mathrm{~mm}$ compr., estipe alvo, ca. $2 \mathrm{~mm}$ compr., levemente triangular, viscídio ca. $1 \mathrm{~mm}$, oval, levemente castanho; ovário ca. $8 \mathrm{~mm}$ compr. Fruto não visto.

Material examinado: BRASIL. MINAS GERAIS. Descoberto. Reserva Biológica da Represa do Grama: 11.XI.2001, V. R. Almeida et al. 26, fl. (CESJ, MBM).

Material adicional examinado: BRASIL. ESPÍRITO SANTO. Cachoeiro do Itapemirim. Vargem Alta, 23.V.1949, A. C. Brade 19881, fl. (RB); sem procedência, 1914, P. CamposPorto 35, fl. (RB); sem procedência, IX.1948, A. C. Brade 19446, fl. (RB).

O gênero Huntleya inclui 10 espécies (Dressler, 1993). Até o início da década de 1990, H. meleagris era a única representante do gênero registrada para o Brasil. Em 1992 foi citada $H$. lucida (Rolfe) Rolfe, para a Amazônia (Silva \& Silva, 2000). H. meleagris ocorre nos estados do Sul e Sudeste do Brasil e Bahia (Pabst \& Dungs, 1977). Pode ser facilmente diferenciada das demais espécies de Orchidaceae da Reserva pela presença de inflorescência uniflora e folhas flabeladas e dísticas. 
11. Liparis nervosa (Thunb. ex Murray) Lindl., Gen. Sp. Orch. Pl. p. 26. 1830.

Erva terrestre, ca. $15 \mathrm{~cm}$ alt. Pseudobulbo vináceo, ca. $6,5 \mathrm{~cm}$ compr., fusiforme, 4folhado. Folhas sésseis, 1,8-25,5 x 1-8,5 cm, imbricadas, lanceoladas a elípticas, ápice agudo, nervuras longitudinais salientes. Inflorescência 32-42,5 cm compr., em racemo, laxa, ereta, terminal. Pedúnculo verde-claro, 18-20 cm compr., ereto. Brácteas do pedúnculo ca. 1,2 x 0,2 cm, lanceoladas, ápice agudo. Brácteas florais 4-8 × $2 \mathrm{~mm}$, lanceoladas a elípticas, ápice agudo. Frutos verdes ca. 1,5 cm compr., com o perianto persistente.

Material examinado: BRASIL. MINAS GERAIS. Descoberto. Reserva Biológica da Represa do Grama: 23.III.2002, R. C. Forzza et al. 2103, fr. (CESJ, MBM).

O gênero Liparis apresenta distribuição cosmopolita e engloba cerca de 350 espécies (Dressler, 1993), com apenas três ocorrendo no Brasil (Pabst \& Dungs, 1975). L. nervosa destaca-se das demais espécies estudadas pela presença de folhas largas, plicadas e pelos pseudobulbos vináceos. Coletada apenas com frutos, não foi possível a descrição de suas flores. Apresenta ampla distribuição geográfica, ocorrendo desde a América Central até o sul do Brasil (Pabst \& Dungs, 1975) e também no Japão. É uma espécie comum em matas secundárias, vegetando sobre detritos (Hoehne, 1949).

12. Oeceoclades maculata (Lindl.) Lindl., Gen. Sp. Orch. Pl. p. 237. 1833.

Figura 2 h-i

Erva terrestre, ca. $15 \mathrm{~cm}$ alt. Pseudobulbo verde-escuro, 2,5-3 cm. compr., piriforme, 1folhado. Folha séssil; lâmina foliar verde-clara, variegada, 7,8-22 x 2-3 cm, elíptica, ápice agudo. Inflorescência ca. 40-44 cm compr., em racemo, pauciflora, laxa, ereta, lateral. Pedúnculo verde-escuro, $18-22 \mathrm{~cm}$ compr., ereto. Brácteas do pedúnculo estramíneas, 2$3 \times 0,7 \mathrm{~cm}$, ovais, amplectivas sobre o pedúnculo, ápice agudo. Brácteas florais estramíneas, 0,3-1 x 0,2 cm, lanceoladas, ápice agudo. Flores pediceladas, calcaradas, cremeesverdeadas; pedicelo ca. $1 \mathrm{~cm}$ compr.; sépala dorsal ca. 1 x 0,3 cm, oblanceolada, ápice arredondado; sépalas laterais ca. 1 x 0,3 cm, falciformes, ápice agudo; pétalas ca. 1 x 0,3 $\mathrm{cm}$, elípticas, ápice arredondado; labelo tetralobado, alvo com duas máculas vináceas, ca. $1,2 \times 1 \mathrm{~cm}$, cálcar claviforme, ca. $3 \mathrm{~mm}$ compr., formado na base do labelo; lobos laterais arredondados, com estrias vináceas; lobos centrais orbiculares; coluna alva, ca. 4 mm compr.; ovário ca. $8 \mathrm{~mm}$ compr.; polínias 4, amarelas, ca. 0,5 mm. Fruto não visto.

Material examinado: BRASIL. MINAS GERAIS. Descoberto. Reserva Biológica da Represa do Grama: 10.III.2002, L. S. Fernandes s.n., fl. (CESJ 36623); 18.V.2002, A. V. Lopes et al. 53, fl. (CESJ).

$\mathrm{O}$ gênero Oeceoclades possui cerca de 30 espécies com ocorrência predominantemente no continente Africano (Dressler, 1993). Para o Brasil, é registrada apenas $O$. maculata que ocorre da Amazônia ao Rio Grande do Sul (Pabst \& Dungs, 1975). Pode ser facilmente diferenciada das demais espécies de Orchidaceae terrestres encontradas na Reserva por possuir pseudobulbo piriforme, com apenas uma folha variegada, e flores com duas máculas vináceas no labelo.

13.Pleurothallis hypnicola Lindl., Edwards's Bot. Reg. 28 (misc.): 75. 1842.

Figura $2 \mathrm{j}-1$

Erva epífita, ca. $12 \mathrm{~cm}$ alt. Caule não intumescido em pseudobulbo. Ramicaule verde, 2-3 cm compr., cilíndrico, 1-foliado; bainhas 1-2 cm compr., amplexicaules, ápice agudo. Folha peciolada, apical; lâmina verdeclara, 6-11 x 1-2 cm, elíptica, margem inteira, ápice agudo. Inflorescência 7,5-10,5 cm compr., em cincínios, multiflora, laxa, terminal, posicionada na axila das folhas. Pedúnculo verde, 2,5-4,5 cm compr., ereto. Brácteas do pedúnculo castanhas, ca. $2 \mathrm{~mm}$ compr., ovais, amplectivas sobre o pedúnculo, ápice agudo. Brácteas florais semelhantes às brácteas do pedúnculo. Flores pediceladas, amarelas; 
pedicelo ca. $3 \mathrm{~mm}$ compr.; sépala dorsal ca. 4 x $2 \mathrm{~mm}$, oblanceolada, ápice agudo, com margem espessada na metade superior; sépalas laterais ca. 4 × $2 \mathrm{~mm}$, parcialmente conatas, ápice agudo, margem espessada próximo ao ápice; pétalas ca. 2 x $0,5 \mathrm{~mm}$, espatuladas, ápice agudo; labelo vináceo, ca. 2 x $1 \mathrm{~mm}$, elíptico, ápice agudo; coluna creme, ca. $2 \mathrm{~mm}$ compr., com alas triangulares; polínias 2, amarelas, ca. 0,5 mm compr.; ovário verde, ca. $1 \mathrm{~mm}$ compr. Fruto não visto.

Material examinado: BRASIL. MINAS GERAIS. Descoberto. Reserva Biológica da Represa do Grama: 21.IV.2002, R. C. Forzza et al. 2187, fl. (CESJ).

Material adicional examinado: BRASIL. RIO DE JANEIRO. Resende. Itatiaia, próximo à pensão Donati, 13.XI.1954, G. F. J. Pabst s.n., fl. (HB 2567); Serra dos Órgãos, II.1958, H. Sick s.n., fl. (HB 8415). Rio de Janeiro. Serra da Carioca, 22.IV.1951, G. F. J. Pabst s.n., fl. (HB 2100). SANTA CATARINA. Ilha de Santa Catarina. Sertão da Lagoa, 12.IV.1952, J. A. Rohr 2183, fl. (HB).

Pleurothallis é um megagênero de cerca de 1000 espécies distribuídas por toda a Região Neotropical (Dressler, 1993). Pleurothallis hypnicola ocorre nos estados das Regiões Sudeste e Sul do Brasil (Pabst \& Dungs, 1975). É uma espécie de porte reduzido, epífita, com os indivíduos apresentando, na área estudada, sépalas e pétalas amarelas e labelo vináceo.

14. Polystachya concreta (Jacq.) Garay \& H.R. Sweet, Fl. Lesser Antilles 1:178. 1974.

Figura $3 a-b$

Erva epífita, ca. $25 \mathrm{~cm}$ alt. Pseudobulbo verde-claro, ca. 2,5 cm compr., fusiforme, 4folhado. Folhas imbricadas; bainha foliar, 4-9 cm compr.; lâmina levemente discolor, 0,5-21 x 0,7-3 cm, elíptica a lanceolada, margem inteira, séssil sobre a bainha, ápice arredondado. Inflorescência 19-35 cm compr., em panicula, multiflora, laxa, pendente, terminal. Pedúnculo verde, $12-20 \mathrm{~cm}$ compr., ereto a levemente recurvado. Brácteas do pedúnculo estramíneas, 2,5-6,2 cm. compr., amplectivas sobre o pedúnculo, ápice agudo. Brácteas florais ca. $2 \times 1 \mathrm{~mm}$, triangulares, ápice agudo a acuminado. Flores pediceladas, não ressupinadas; pedicelo alvo, inconspícuo; sépala dorsal amarela, ca. 2 x $1 \mathrm{~mm}$, oval, côncava, ápice agudo; sépalas laterais amarelas, ca. $3 \times 2 \mathrm{~mm}$, ovais, margem inferior convoluta próxima à base, ápice agudo; pétalas amarelas, ca. $3 \times 0,5 \mathrm{~mm}$, oblongas a oblanceoladas, ápice retuso; labelo alvo, ca. 3 x $3 \mathrm{~mm}$, trilobado, ápice retuso, lobo central com pseudopólen, calo ca. $1 \mathrm{~mm}$ compr., próximo à base do lobo central; coluna alva, ca. $1 \mathrm{~mm}$ compr.; polínias não vistas; ovário ca. $5 \mathrm{~mm}$ compr., fusiforme. Fruto verde, ca. $9 \mathrm{~mm}$ compr., fusiforme.

Material examinado: BRASIL. MINAS GERAIS. Descoberto. Reserva Biológica da Represa do Grama: II.2001, L. D. Meireles s.n., fl./fr. (CESJ 33817); 27.V.2001, V. R. Almeida et al. 6, fr. (CESJ, MBM); 24.II.2000, P. C. Zampa s.n., fl. (CESJ 31037); 21.IV.2001, R. M. Castro et al. 286, fr. (CESJ).

O gênero Polystachya abriga cerca de 120 espécies, sendo predominantemente africano (Dressler, 1993). Para o Brasil são registradas 12 espécies. $P$. concreta apresenta ampla distribuição no Brasil, ocorrendo desde a Amazônia até o Rio Grande do Sul (Pabst \& Dungs, 1975). Na Reserva são encontradas grandes populações desta espécie, preferencialmente em locais mais úmidos.

15. Polystachya micrantha Schltr., Repert. Spec. Nov. Regni Veg. Beih.35: 81. 1925.

Figura $3 \mathrm{c}$

Erva rupícola, ca. $7 \mathrm{~cm}$ alt. Pseudobulbo verde-escuro, ca. $5 \mathrm{~mm}$ compr., oval, 4folhado. Folhas imbricadas; bainha foliar verdeclara, ca. $1 \mathrm{~cm}$ compr. Lâmina verde-clara, 5,5-7,5 x 0,6-1 cm., elíptica, margem inteira, séssil sobre a bainha, ápice arredondado. Inflorescência ca. 6,5 cm compr., em racemo, pauciflora, laxa, ereta, terminal. Pedúnculo verde, ca. $5 \mathrm{~cm}$ compr., ereto. Brácteas do pedúnculo estramíneas, ca. $2 \mathrm{~cm}$ compr., 


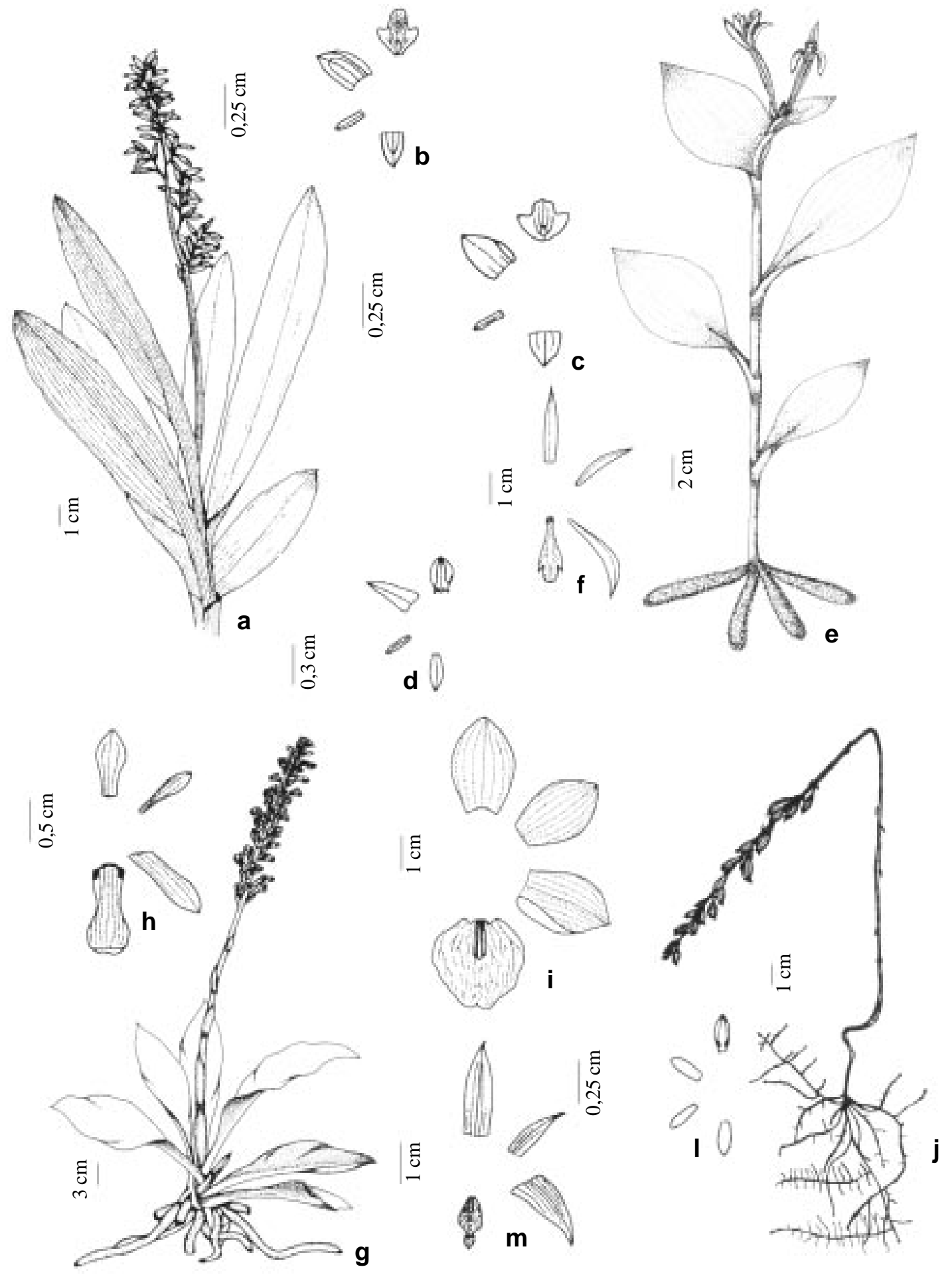

Figura 3.a-b. Polystachya concreta; c. P. micrantha; d. Prescottia stachyodes.; e-f. Psilochilus modestus; g-h. Sauroglossum nitidum; i. Warrea warreana; $\mathrm{j}-1$. Wullschlaegelia aphylla; $\mathrm{m}$. Xylobium variegatum. 
amplectivas sobre o pedúnculo, membranáceas, ápice acuminado. Brácteas florais ca. 0,5 mm compr., triangulares, ápice acuminado. Flores pediceladas, não ressupinadas, verde-claras; pedicelo ca. $1 \mathrm{~mm}$ compr.; sépala dorsal ca. 2 × $2 \mathrm{~mm}$, oval, côncava., ápice agudo; sépalas laterais ca. 3 x $2 \mathrm{~mm}$, ovais, côncavas, margem inferior convoluta próximo à base, ápice agudo; pétalas ca. $2 \times 0,5 \mathrm{~mm}$, oblongas, ápice arredondado; labelo trilobado, ca. 2 × $3 \mathrm{~mm}$, ápice truncado, calo castanho próximo à base do labelo; coluna alva, ca. $1 \mathrm{~mm}$ compr.; polínias não vistas; ovário ca. $2 \mathrm{~mm}$ compr., fusiforme. Frutos imaturos verdes, ca. $8 \mathrm{~mm}$ compr., fusiformes. Material examinado: BRASIL. MINAS GERAIS. Descoberto. Reserva Biológica da Represa do Grama: 12.I.2002, L. Menini Neto et al. 1, fl./fr. (CESJ).

Polystachya micrantha é citada por Pabst \& Dungs (1975) apenas para o estados de São Paulo e Rio Grande do Sul, de modo que este é o primeiro registro da espécie para o estado de Minas Gerais. Na Reserva foram observadas apenas duas pequenas populações próximas de cursos d'água.

16. Prescottia stachyodes (Sw.) Lindl., Edward's Bot. Reg. 22: t. 1915. 1836.

Figura $3 \mathrm{~d}$

Erva terrestre, ca. $50 \mathrm{~cm}$ alt. Caule não intumescido em pseudobulbo. Folhas pecioladas; pecíolo castanho 33,5-43,5 cm compr.; lâmina verde, variegada, 22-23,5 x 11$14 \mathrm{~cm}$, elíptica, base cuneada a atenuada, margem inteira, ápice agudo. Inflorescência ca. $1 \mathrm{~m}$ compr., em espiga, multiflora, laxa, ereta, terminal. Pedúnculo róseo, 81,5-86 cm compr., ereto. Brácteas do pedúnculo castanhas a levemente rosadas, 2-8,5 cm compr., amplectivas sobre o pedúnculo, ápice agudo. Brácteas florais creme, 0,5-1,5 x 0,1-0,5 cm, diminuindo de tamanho em direção ao ápice, lanceoladas, ápice longo-acuminado. Flores sésseis, cremes a verdes, não ressupinadas; sépala dorsal ca. 3 x $1 \mathrm{~mm}$, elíptica, recurvada, ápice agudo; sépalas laterais ca. 3 x $1 \mathrm{~mm}$, lanceoladas, ápice agudo; pétalas ca. 2 x 0,5 $\mathrm{mm}$, oblongas, recurvadas, ápice arredondado; labelo ca. 2 × $2 \mathrm{~mm}$, cuculado, com duas aurículas na base; coluna ca. $2 \mathrm{~mm}$ compr; polínias não vistas; ovário ca. $6 \mathrm{~mm}$ compr. Fruto ca. $1 \mathrm{~cm}$ compr., fusiforme.

Material examinado: BRASIL. MINAS GERAIS. Descoberto. Reserva Biológica da Represa do Grama: 30.IX.2000, L. D. Meireles et al. s.n., fl. (CESJ 31444, SP); 01.IX.2001, R. C. Forzza et al. 1849, fl. (CESJ); 31.X.2001, R. M. Castro et al. 655, fl. (CESJ).

Material adicional examinado: BRASIL. RIO DE JANEIRO. Paraty. Morro da Pedra Rolada, ca. 400 m.s.m., APA Cairuçú, 23.VIII.1995, M. G. Bovini et al. 873, fl. (RB). Rio de Janeiro. Vertente do Sumaré, VII.1969, D. Sucre 5749, fl. (RB).

Prescottia é um gênero com 21 espécies (Dressler, 1993), das quais 17 são registradas para o Brasil (Pabst \& Dungs, 1975). P. stachyodes apresenta ampla distribuição geográfica ocorrendo do México ao sul do Brasil. É uma espécie relativamente comum na Reserva, onde indivíduos isolados são encontrados em vários pontos dentro da mata, sempre em locais sombreados e úmidos.

17. Psilochilus modestus Barb. Rodr., Gen. Sp. Orchid. 2: 273. 1882.

Figura 3 e-f

Erva terrestre, ca. $30 \mathrm{~cm}$ alt. Caule cilíndrico, não intumescido em pseudobulbo. Folhas rosuladas, sésseis; bainha foliar 3,4-4 cm compr., a metade inferior amplexicaule, a metade superior livre. Lâmina foliar discolor, 7,8-9,4 x 4,5-4,8 cm, oval, margem levemente revoluta, ápice agudo. Inflorescência ca. 1,3 $\mathrm{cm}$ compr., em racemo, pauciflora, ereta, terminal. Pedúnculo ca. $2 \mathrm{~cm}$ compr., ereto. Brácteas do pedúnculo semelhantes à lâmina foliar, ca. 3,8 x 1,6 cm. Brácteas florais ca. 1 cm compr., lanceoladas, ápice agudo. Flores pediceladas; pedicelo ca. $1 \mathrm{~cm}$ compr.; sépala dorsal ca. 2,3 x 0,2 cm, lanceolada, ápice agudo; sépalas laterais ca. 2,3 x 0,3 cm, 
lanceoladas, ápice agudo; pétalas ca. 2 x 0,2 $\mathrm{cm}$, lanceoladas, ápice agudo; labelo trilobado, ca. 1,8 x 0,7 cm, lobos laterais levemente triangulares, ca. $2 \mathrm{~mm}$ compr., ápice agudo, lobo central orbicular, ca. 5 x $4 \mathrm{~mm}$; coluna ca. 1,3 cm compr.; polínias não vistas; ovário ca. $3 \mathrm{~cm}$ compr. Fruto não visto.

Material examinado: BRASIL. MINAS GERAIS. Descoberto. Reserva Biológica da Represa do Grama: 21.IV.2002, R. C. Forzza et al. 2192, fl. (CESJ).

Material adicional examinado: BRASIL. ESPÍRITO SANTO. Domingos Martins. 23.III.1976, R. Kautsky 539, fl.(HB); 13.II.1978, R. Kautsky 581, fl. (HB). SÃO PAULO. Angatuba. Fazenda do Serviço Florestal: 23.II.1966, M. Emmerich \& R. Dressler 2841, fl. (HB). SANTA CATARINA. Araguari. Barra do Sul, 08.IV.1953, R. Reitz \& R. Klein 506, fl. (HB); Ilha de Santa Catarina. Sertão da Lagoa, 12.X.1958, J. A. Rohr 2340, (HB); sem procedência, 26.II.1951, J. A. Rohr s.n., fl. (HB 2038).

O gênero Psilochilus possui sete espécies (Dressler, 1993) das quais apenas $P$. modestus e $P$. dusenianus Kraenzl. ex Garay \& Dunst. ocorrem em território brasileiro (Pabst \& Dungs, 1975). P. modestus apresenta distribuição nos estados das Regiões Sul e Sudeste do Brasil. Na Reserva apenas poucos indivíduos isolados foram observados.

18. Sauroglossum nitidum (Vell.) Schltr., Beih. Bot. Centralbl. 37: 376. 1920.

Figura $3 \mathrm{~g}-\mathrm{h}$

Erva terrestre ca. $45 \mathrm{~cm}$ alt. Caule não intumescido em pseudobulbo. Folhas rosuladas, com a base estreitada, canaliculada, séssil; lâmina verde, $20-35$ x 4,5-7,5 cm, elíptica, margem inteira, ápice agudo. Inflorescência 35$100 \mathrm{~cm}$ compr., em racemo, ereta, multiflora, laxa, terminal. Pedúnculo $25-80 \mathrm{~cm}$ compr., verde, ereto, pubérulo. Brácteas do pedúnculo verdes, $2-15$ x 0,5-1,5 cm, sendo as inferiores amplectivas sobre o pedúnculo, ápice acuminado. Brácteas florais 0,5-2 x 0,2-0,5 cm, pubérulas na face abaxial, ápice acuminado.
Flores pediceladas; pedicelo verde, ca. $3 \mathrm{~mm}$ compr.; sépala dorsal verde, ca. 8 × $3 \mathrm{~mm}$, oblanceoladas, pubérulas, ápice levemente arredondado; sépalas laterais verdes, ca. $1 \mathrm{x}$ $0,3 \mathrm{~cm}$, oblongas, pubérulas, ápice arredondado; pétalas verdes, ca. 8 × $2 \mathrm{~mm}$, espatuladas, pubérulas, ápice arredondado; labelo ca. 9 × $5 \mathrm{~mm}$, dois calos na base próximos à margem, ápice retuso, levemente revoluto; coluna ca. $6 \mathrm{~mm}$ compr.; polínias 4 , ca. $2 \mathrm{~mm}$, cremes; viscídio castanho, $0,5 \mathrm{~mm}$, oval; ovário ca. $1 \mathrm{~cm}$ compr., fusiforme, pubérulo. Fruto não visto.

Material examinado: BRASIL. MINAS GERAIS. Descoberto. Reserva Biológica da Represa do Grama: VI.2001, R. M. Castro 452, fl. (CESJ); 16.II.2002, R. C. Forzza et al. 2210, fl. (CESJ, MBM).

O gênero Sauroglossum apresenta 9 espécies (Dressler, 1993) ocorrentes na América do Sul, dentre as quais apenas $S$. nitidum ocorre no Brasil. Tem sua distribuição geográfica registrada para DF, MG, RJ, SP, PR, RS e a Argentina (Pabst \& Dungs, 1975). S. nitidum é uma espécie comum na área da Reserva, encontrada em vários pontos no interior da mata, sempre com indivíduos isolados.

19. Vanilla cf. gardneri Rolfe, Bull. Misc. Inform. Kew 177. 1895.

Erva lianescente. Caule não intumescido em pseudobulbo. Folhas sésseis, dispostas disticamente ao longo do caule. Lâmina verde, 12-14 x 3-3,5 cm, elíptica, ápice acuminado, margem levemente revoluta. Inflorescência ca. $3 \mathrm{~cm}$ compr., em racemo, pauciflora, laxa, lateral; brácteas florais ca. 4 x $4 \mathrm{~mm}$, triangulares, ápice agudo, côncavas. Flores não vistas. Frutos verdes, $5-9 \mathrm{~cm}$ compr., fusiformes.

Material examinado: BRASIL. MINAS GERAIS. Descoberto. Reserva Biológica da Represa do Grama: 23.III.2002, R. C. Forzza et al. 2115, fr. (CESJ).

O gênero Vanilla apresenta distribuição Pantropical e abriga cerca de 100 espécies 
(Dressler, 1993), das quais 30 são encontradas em território brasileiro (Pabst \& Dungs 1975). Vanilla cf. gardneri foi coletada apenas em fruto o que impossibilitou a identificação mais precisa do material. Pode ser facilmente diferenciada das demais espécies de Orchidaceae da Reserva pelo hábito lianescente.

20. Warrea warreana (Lodd. ex Lindl.) C. Schweinf., Bot. Mus. Leafl. 17: 55. 1955.

Figura 3 i

Erva terrestre, 1-1,10 m alt. Pseudobulbos verdes, ca. $7 \mathrm{~cm}$ compr., fusiformes, multifoliados. Folhas basais sésseis, 16-33 x 3 $\mathrm{cm}$, lanceoladas, nervuras longitudinais salientes, ápice agudo. Folhas apicais pecioladas; pecíolo 19-37 cm compr.; lâmina verde, ca. 75 x $11 \mathrm{~cm}$, elíptica, nervuras longitudinais salientes, ápice acuminado. Inflorescência $85-123 \mathrm{~cm}$ compr., em racemo, multiflora, laxa, ereta, lateral. Pedúnculo verde, 70-86 cm compr., ereto. Brácteas do pedúnculo 1,5-3,5 x 1,5 cm, ovais, ápice agudo, amplectivas sobre o pedúnculo. Brácteas florais verdes, $0,5-1 \times 0,5 \mathrm{~cm}$, lanceoladas, ápice agudo. Flores pediceladas; pedicelo verde, ca. $1,5 \mathrm{~cm}$ compr.; sépala dorsal alva, levemente esverdeada na face externa, ca. $2,7 \times 1,8 \mathrm{~cm}$, oboval, ápice agudo; sépalas laterais alvas, ca. $2,7 \times 1,8 \mathrm{~cm}$, oblongas, margem inferior convoluta até próximo à metade do comprimento, ápice agudo; pétalas alvas, ca. 2,4 x 1,6 cm, elípticas, ápice agudo; labelo vináceo com base levemente amarelada, ca. $2,2 \times 2,2 \mathrm{~cm}$, largamente obovado, com três calos longitudinais basais, ápice retuso; coluna alva, ca. 1,2 cm compr., rostrada; rostro triangular, ca. $2 \mathrm{~mm}$ compr.; pé da coluna ca. $5 \mathrm{~mm}$ compr.; polínias 4, amarelo-claras, $2 \mathrm{~mm}$, ovais; viscídio pentagonal, ca. $2 \mathrm{~mm}$ larg.; ovário ca. $1 \mathrm{~cm}$ compr. Frutos imaturos verdes, ca. $4,5 \mathrm{~cm}$ compr.

Material examinado: BRASIL. MINAS GERAIS. Descoberto. Reserva Biológica da Represa do Grama: 20.IV.2002, R. C. Forzza et al. 2180, fl. (CESJ).
Material adicional examinado: BRASIL. PARANÁ. Guairá. Usina Hidrelétrica de Sete Quedas: 24.I.1967, G. Hatschbach 15901, fl. (HB); s.d., G. Hatschbach \& Haas s.n., fl. (HB 41712).

Warrea é um gênero com apenas quatro espécies (Dressler, 1993), das quais somente W. warreana é registrada para o território brasileiro, com ocorrência em matas úmidas nos estados das Regiões Sudeste e Sul do Brasil (exceto Santa Catarina) e na Argentina (Pabst \& Dungs, 1977).

21. Wullschlaegelia aphylla (Sw.) Rchb. f., Bot. Zeitung (Berlin) 21: 131. 1863.

Figura $3 \mathrm{j}-1$

Erva saprófita, $25-45 \mathrm{~cm}$ alt. Caule não intumescidos em pseudobulbos. Áfila. Inflorescência 24-47 cm compr., em racemo, multiflora, laxa, ereta, terminal. Pedúnculo ereto, $15-29 \mathrm{~cm}$ compr. Brácteas do pedúnculo ca. 5 x $2 \mathrm{~mm}$, lanceoladas, ápice acuminado. Brácteas florais ca. $5 \times 2 \mathrm{~mm}$, diminuindo de tamanho em direção ao ápice da inflorescência lanceoladas, membranáceas, ápice acuminado. Flores pediceladas, não ressupinadas; pedicelo ca. $3 \mathrm{~mm}$ compr.; sépala dorsal ca. 2 x $1 \mathrm{~mm}$, elíptica, ápice arredondado; sépalas laterais 2 x $1 \mathrm{~mm}$, elípticas, ápice arredondado; pétalas $1 \times 0,5 \mathrm{~mm}$, elípticas, ápice arredondado; labelo cuculado, $2 \times 1 \mathrm{~mm}$, ápice agudo, com dois calos esféricos, escuros, próximos à base; polínias não vistas. Frutos alvos, ca. $1 \mathrm{~cm}$ compr., ovais.

Material examinado: BRASIL. MINAS GERAIS. Descoberto. Reserva Biológica da Represa do Grama: 27.I.2002, R. C. Forzza et al. 2067, fr. (BCHB, CESJ, CTES, HUFU, MBM, RB, SP, SPF, UB).

Material adicional examinado: BRASIL. MATO GROSSO. Serra Ricardo Franco, 800 m.s.m., XII.1977, P. G. Windisch 1800, fl. (HB). GOIÁS. Corumbá de Goiás. Rodovia para Niquelândia, 28.I.1968, H. S. Irwin et al. 42718, fr. (HB). RIO DE JANEIRO. Rio de Janeiro. Corcovado, s.d., W. Schwacke 8981, fr. (RB); Matas do Pai Ricardo, 21.II.1945, $T$. 
Occhioni s.n., fr. (RB 132041); Grota do Pai Ricardo, entre 500-550 m.s.m., 22.XII.1971, D. Sucre 8147, fr. (RB); Matas da Lagoinha, 21.I.1945, T. Occhioni 94, fr. (RB). PARANÁ. Ponta Grossa. Parque Vila Velha, s.d., G. Hatschbach \& O. Guimarães 16503, fl./fr. (HB).

Wullschlaegelia é um gênero com apenas duas espécies saprófitas, W. aphylla e W. calcarata Benth. (Born et al., 1999). W. calcarata ocorre desde a República Dominicana até o norte do Brasil e apresenta flores ressupinadas. W. aphylla apresenta ampla distribuição geográfica, ocorrendo desde a América Central até o Paraguai e possui flores não ressupinadas. Na revisão recente do gênero (Born et al. 1999) esta espécie é citada para Minas Gerais apenas por uma coleta realizada em 1865. Na Reserva foi observada uma grande população, ocorrendo em local muito sombreado e com serapilheira abundante.

22. Xylobium variegatum (Ruiz \& Pav.) Garay \& Dunst., Venez. Orchid. Ill. 2: 11. 1961.

Figura $3 \mathrm{~m}$

Erva epífita, ca. $50 \mathrm{~cm}$ alt. Pseudobulbos verde-escuros, 4-9 cm compr., fusiformes a ovais, 2-folhados, envoltos por bainhas paleáceas. Folhas pecioladas; pecíolo 7-11 cm compr.; lâmina foliar verde 29-39 x 2,5-6,5 cm, elíptica, base atenuada, nervuras longitudinais salientes, ápice acuminado. Inflorescência 17$24 \mathrm{~cm}$ compr., em racemo, pauciflora, laxa, ereta, lateral. Pedúnculo $7-10 \mathrm{~cm}$ compr., ereto. Brácteas do pedúnculo castanho-claras, 1,5-4 cm compr., amplectivas ao pedúnculo, paleáceas, ápice agudo. Brácteas florais alvas, 1-2,5 x 0,2-0,4 cm, lanceoladas, ápice acuminado. Flores pediceladas; pedicelo creme-esverdeado a vináceo, ca. $8 \mathrm{~mm}$. compr.; sépalas alvas, com estrias vináceas na face abaxial, recurvadas; sépala dorsal ca. 1,7 x $0,5 \mathrm{~cm}$, oblongo-lanceolada, ápice acuminado; sépalas laterais ca. 2 × 0,6 cm, lanceoladas, base assimétrica, ápice acuminado; pétalas alvas com estrias vináceas na face adaxial, ca.
$1,5 \times 0,4 \mathrm{~cm}$, recurvadas, lanceoladas, ápice acuminado; labelo trilobado, alvo com estrias e lobo central vináceos, ca. 1,6 x 0,6 cm, lobos laterais verruculosos no ápice e lobo central totalmente verruculoso, calo longitudinal creme, no centro do labelo, ca. $5 \mathrm{~mm}$ compr.; coluna creme, ca. 0,5 cm compr., pé da coluna ca. 0,3 cm compr.; polínias 4 , amarelo-claras, ca. 0,1 cm compr.; ovário ca. $0,8 \mathrm{~cm}$ compr. Frutos castanho-escuros, ca. $3 \mathrm{~cm}$ compr.

Material examinado: BRASIL. MINAS GERAIS. Descoberto. Reserva Biológica da Represa do Grama, 11.XI.2001, V. R. Almeida et al. 24, fl./fr. (BHCB, CESJ, MBM, UB).

Material adicional examinado: BRASIL. MINAS GERAIS. Olaria. Desfiladeiro do Funil, Rio do Peixe, I.1998, M. Brügger et al. s.n., fr. (CESJ 30054). ESPÍRITO SANTO. Domingos Martins. 10.I.1947, L. Krieger s.n., fl. (CESJ 15155).

O gênero Xylobium apresenta 30 espécies (Dressler, 1993), das quais apenas quatro são registradas para o Brasil (Pabst \& Dungs, 1977). X. variegatum apresenta ampla distribuição geográfica ocorrendo nos estados do PA, RJ, SP, PR, SC, MT e na Costa Rica, Venezuela, Equador, Peru e Bolívia (Pabst \& Dungs, 1977).

\section{CONSIDERAÇÕES FINAIS}

A grande maioria dos levantamentos florísticos realizados para as florestas de Minas Gerais, se concentram no extrato arbóreo e arbustivo. Os estudos de flora que contemplam famílias de Monocotiledôneas em Minas Gerais, em geral são realizados nos campos rupestres. Para a Zona da Mata de Minas Gerais apenas três estudos foram desenvolvidos para Orchidaceae (Leoni, 1991, 1993 e 1994) todos para o Leste da Zona da Mata.

Para a Serra do Araponga, Leoni (1991) registrou 63 espécies, das quais 7 ocorrem na Reserva Biológica da Represa do Grama: Encyclia patens (citada como E. odoratissima), Epidendrum densiflorum (citado como E. paniculatum) E. secundum 
(citado como E. cf. elongatum Jacq.), Polystachya concreta (citada como $P$. estrellensis Rchb. f.), Gomesa recurva e Pleurothallis hypnicola.

Para o município de Carangola, Leoni (1993) registrou 162 espécies. Dentre estas, 12 ocorrem na Reserva: Catasetum cernuum, Encyclia patens (citada como $E$. odoratissima), Epidendrum densiflorum (citado como E. paniculatum), E. secundum (citado como E. aff. elongatum), Eurystyles actinosophila, Gomesa recurva, Liparis nervosa, Oeceoclades maculata, Polystachya concreta (citada como $P$. estrellensis), Pleurothallis hypnicola, Warrea warreana (citada como W. tricolor Lindl.) e Xylobium variegatum.

Nos levantamentos supracitados, 13 espécies ocorrentes na Reserva não foram registradas: Campylocentrum linearifolium, Comparettia coccinea, Polystachya micrantha, Liparis nervosa, Sauroglossum nitidum, Cyrtopodium cardiochilum, Eltroplectris janeirensis, Huntleya meleagris, Prescottia stachyodes, Psilochilus modestus, Vanilla cf. gardneri, Xylobium variegatum e Wullschlaegelia aphylla. Estas espécies indicam que diversos fragmentos florestais devem ser inventariados e conservados para que a verdadeira riqueza das matas estacionais de Minas Gerais seja conhecida e conservada.

\section{AGRADECIMENTOS}

Os autores agradecem a FAPEMIG, CNPq e UFJF pelas bolsas concedidas. A Patrícia Carneiro Lobo Faria, coordenadora do projeto de inventário florístico da Reserva, pelo apoio nas diversas etapas deste estudo. À Viviane Scalon, Cláudio Nicoletti e a dois assessores anônimos pelas valiosas sugestões.

\section{REFERÊNCIAS BIBLIOGRÁFICAS}

Barros, F. 1996. Notas taxonômicas para espécies brasileiras dos gêneros Epidendrum, Platystele, Pleurothallis e
Scaphyglottis (Orchidaceae). Acta bot. bras. 10 (1): 139 - 151.

2002. Notas taxonômicas para espécies brasileiras dos gêneros Epidendrum e Heterotaxis (Orchidaceae). Hoehnea 29 (2): 109113.

Born, M. G.; Maas, P. J. M.; Dressler, R. L. \& Westra, L. Y. T. 1999. A revision of the saprophytic orchid genera Wullschlaegelia and Uleiorchis. Bot. Jahrb. Syst. 121 (1): 45-74

Campacci, M. A. \& Kautsky, R. A. 1999. Eltroplectris assumpcaoana Campacci \& Kautsky sp. nov. Bol. CAOB 38: 108111.

Castro Neto, V. P. \& Campacci, M. A. 2000. Icones Orchidacearum Brasilienses I, CAOB. São Paulo, 100 tab.

Dahlgren, R. M. T.; Clifford, H. T. \& Yeo, P. F. 1985. The Families of the Monocotyledons. Springer Verlag. Berlin.

Dressler, R. L. 1981. The Orchids, Natural History and Classification. Harvard University Press. Harvard.

1993. Phylogeny and Classification of the Orchid Family. Dioscorides Press. Portland.

Garay, L. A. 1980. A generic revision of the Spiranthinae. Bot. Mus. Leaf. 28 (4): 277-425.

Hoehne, F. C. 1949. Iconografia de Orchidaceas do Brasil. Secretaria da Agricultura, Indústria e Comércio. São Paulo.

Judd, W. S.; Campbell, C. S.; Kellogg, E. A. \& Stevens, P. F. 1999. Plant Systematics: A Phylogenetic Approach. Sinauer Associates. Sunderland.

Leoni, L. S. 1991. Contribuição para o conhecimento da família Orchidaceae na Serra da Araponga (Levantamento preliminar). Pabstia 2 (2): 1-9. 
1993. Orchidaceae em Carangola, Minas Gerais: Ecologia e Fitogeografia. Pabstia 4(2): 1-19. 1994. Orchidaceae do Vale do Rio Carangola, MG. Pabstia 5(3): 1-8.

Meira-Neto, J. A. A.; Souza, A. L.; Silva, A. F. \& Paula, A. 1997. Estrutura de uma floresta estacional semidecidual submontana em are diretamente afetada pela usina Hidrelétrica de Pilar, Ponte Nova, Zona da Mata de Minas Gerais. Revista Árvore 21(3): 337-344.

Menezes, L. C. 2000. Genus Cyrtopodium Espécies Brasileiras. Ed. IB AMA. Brasília.

Oliveira-Filho, A. T. de; Scolforo, J. R. S. \& Melo, J. M. 1994. Composição florística e estrutura comunitária de um remanescente de floresta semidecídua montana em Lavras, MG. Rev. Bras. Bot. 17(2): 167-182.

Pabst, G. F. J. \& Dungs, F. 1975. Orchidaceae Brasilienses. Band I, Kurt Schmersow. Hildesheim. 1977. Orchidaceae Brasilienses. Band II, Kurt Schmersow. Hildesheim.

Pinheiro, F. \& Barros, F. 2002. Análise morfométrica do complexo Epidendrum secundum (Orchidaceae) no Brasil. In: Anais do $53^{\circ}$ Congresso Nacional de Botânica e $25^{\circ}$ Reunião Nordestina de Botânica. Recife, p. 459.

Radford, A. E.; Dickison, W. C.; Massey, J. R. \& Bell, C. R. 1974. Vascular plant systematics. Harper \& Row. New York.

Silva, A. F. 2000. In: M. P. Mendonça. \& L. V. Lins (Eds.), Lista Vermelha das espécies Ameaçadas de Extinção da Flora de Minas Gerais. Fundação Biodiversitas Fundação Zoo-Botânica de Belo Horizonte, Belo Horizonte.

Silva, J. B. F. \& Silva, M. F. F. 2000. $C D$ Orquídeas Nativas da Amazônia Brasileira. Museu Paraense Emílio Goeldi, Belém.
Silva, M. F. F. \& Oliveira, A. T. 1998. Catasetum cucullatum, uma nova espécie de Orchidaceae para o estado do Amazonas, Brasil. Bol. Mus. Para. Emilio Goeldi, sér. Bot. 14 (1): 63-67.

Toscano-de-Brito, A. L. 1995. Orchidaceae. In: B.L. Stannard (ed.), Flora of the Pico das Almas, Chapada Diamantina, Bahia - Brazil, Royal Botanic Gardens. Kew. p. 725-767. 